\title{
Deconstruction and Genealogy of Latin American Good Living (Buen Vivir). The (Triune) Good Living and Its Diverse Intellectual Wellsprings
}

\author{
Antonio Luis Hidalgo-Capitán and Ana Patricia Cubillo-Guevara
}

\begin{abstract}
The purpose of this chapter is to identify the different meanings of Latin American Good Living (buen vivir) and its diverse intellectual wellsprings, with a focus on the political economy of development. The authors try to answer the following questions: What different types of Good Living lie behind the overall concept? What intellectual wellsprings have the authors drunk from? The authors use the methodological strategies of deconstruction and conceptual genealogy, based on a broad bibliographic review. They conclude that three different types of Latin American Good Living exist: 'indigenist' and 'pachamamist', socialist and statist, and 'ecologist' and 'post-developmentalist'. Moreover, they argue that synthesised notions of the concept exist. These versions are associated with different intellectual influences, such as sumak kawsay, suma qamaña and allin kawsay; the Andean world view; development with identity; the theory of reciprocity; post-development; liberation theology; dependency theory; the theory of 'coloniality'; sustainable development; world-system theory; human development; endogenous development; eco-socialism; twenty-first century socialism; social justice; the economics of happiness; eudaemony; the economic theory of relational goods; the social and solidarity economy; intercultural feminism; the feminism of care; eco-feminism; the self-sufficient economy; community economy; barefoot economics and human scale development theory; the Buddhist economy; 'post-extractivism'; 'de-growth'; deep ecology and the theory of conviviality.
\end{abstract}

\section{Introduction}

At the beginning of the twenty-first century, Latin American Good Living ${ }^{1}$ became a most innovative concept and offered great potential for the political

1 Buen Vivir in Spanish. In Bolivia, the preferred expression is Living Well (Vivir Bien).

(C) HIDALGO-CAPITÁN AND CUBILLO-GUEVARA, 2017 | DOI 10.1163/9789004351677_004

This is an open access chapter distributed under the terms of the CC-BY-NC License. 
economy of development (Hidalgo-Capitán, 2011). Its relevance is considered equivalent to that of the Latin American dependence concept of the 197os and 1980s. Yet the concept - as was the case with its predecessor, 'dependence'is far from universally understood ${ }^{2}$ despite its frequent use in both political and academic milieu. It is possible that the very frequency of its use has led to many diverging definitions and its interpretation depends on the ideological position of authors and their intellectual influences.

We have formulated the following questions on this point: What are the different types of Good Livings ${ }^{3}$ behind the concept? From which intellectual wellsprings have the different authors who have made significant contributions to Latin American Good Living drunk? In our attempt to identify these Latin Americans and their intellectual wellsprings, and based on a broad bibliographic review, we will use two methodological strategies: concept deconstruction (Derrida, 1967) and concept genealogy or archaeology (Foucault, 1969). ${ }^{4}$ As such, this chapter is divided into two main sections, one on deconstructing Good Living and the other on the genealogy of this concept, which is derived from the concept itself.

\section{2 \\ The Trinity of Good Living}

Good Living can be defined as a way of living in harmony with oneself (identity), with society (equity) and with nature (sustainability) (Hidalgo-Capitán and Cubillo-Guevara, 2015). This definition is commonly accepted by the majority of intellectuals and politicians who use the term and, in addition,

2 The concept of Good Living is not part of the international agenda for development, currently embodied in the Sustainable Development Goals. Nevertheless, far from being a limitation for discursive enrichment, this can be considered an advantage given that its absence from the agenda has sparked an intense intellectual debate which would not have come about if the concept had been subjected to 'operational simplification', which typically occurs in the case of concepts that are accepted by international institutions.

3 Here the expression Good Livings is used differently than by Acosta (2013). We are referring to the fact that there are various definitions, which stem from the application of different schools of thought; this is not an indication that this concept has different meanings in each global community.

4 Previous work with a somewhat similar focus includes that on the genealogy of Good Living in the Ecuadorian constitution (Cortez, 2009), the identification of three schools of thought on Good Living (Le Quang and Vercoutère, 2013; Cubillo-Guevara, Hidalgo-Capitán and Domínguez-Gómez, 2014; Hidalgo-Capitán and Cubillo-Guevara, 2015) or the maze of discourse on Good Living (Vanhults, 2015). 
convert Good Living into a concept of universal acceptance. ${ }^{5}$ But the consensus ends here, given that this way of living in harmony takes on very different meanings according to the ideological position of each intellectual or politician that uses the concept. As such, from a 'de-constructivist' perspective (Derrida, 1967), we contend that there are at least three ways of understanding Good Living - one 'indigenist' and 'pachamamist' (which prioritises identity as an objective), one which is socialist and statist (which prioritises equity) and another which is 'ecologist' and 'post-developmentalist' (which prioritises sustainability) (Figure 3.1). Each of these versions corresponds to an ideological

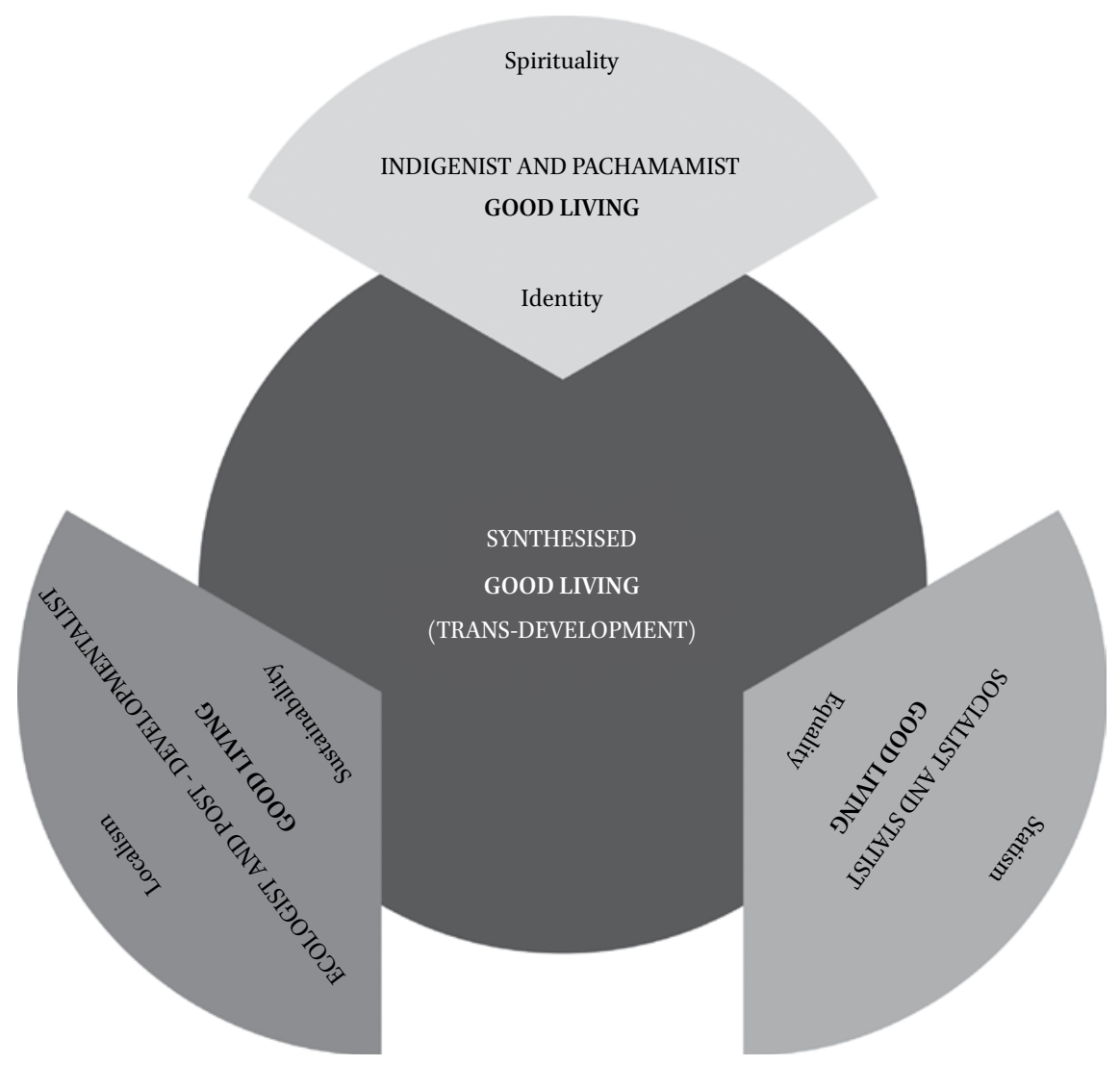

FIGURE 3.1 The trinity of Latin American Good Living. SOURCE: AUTHORS.

5 The acceptance of the discourse of Good Living goes beyond the existence of revolutionary governments, or the greater or lesser degree of importance of the same in indigenous communities or in the populations of different countries. 
school of thought that attempts to use the concept of Good Living for political purposes $^{6}$ in a context in which the Latin American Left is jockeying to establish hegemony in a post-neo-liberal era. ${ }^{7}$

Although there are currently three conceptions of Good Living that are discursively opposed, these schools of thought flowed together during the constitutional processes in Ecuador and Bolivia and it is reasonable to hope that the same will occur again, in these cases, through a synthesised concept that is more academic than political and that considers identity, equity and sustainability as of equal weight. This would contribute to transforming Latin American societies into pluri-national, post-capitalist and bio-centric societies under a trans-modern and trans-development conception that transcends the paradigms of well-being, such as pre-modern subsistence, modern development and postmodern development (Cubillo-Guevara and Hidalgo-Capitán, $2015 \mathrm{~b}$ ). All of this converts Good Living into a trinity, a triune concept, a concept that is at the same time one and triune-three different conceptions and only one true Good Living (supposedly).

\subsection{Good Living ('Indigenist' and 'Pachamamist')}

The 'indigenist' and 'pachamamist' version of Good Living is part of the school of thought of indigenous and 'indigenist' intellectuals, many of whom are associated with Latin American indigenous movements. Particularly noteworthy individuals in this regard have come from Ecuador (Viteri, 2000, 2003; Macas, 2010; Maldonado, 2010a, 2010b; Oviedo, 2011; Dávalos, 2008a, 2008b, 2011; Simbaña, 2011; Pacari, 2013), Bolivia (Yampara, 2001; Medina, 2001, 2002, 2006, 2011; Albó, 2009, 2010; Huanacuni, 2010; Choquehuanca, 2010a, 2010b; Bautista,

6 With the exception of genuine sumak kawsay (Cubillo-Guevara and Hidalgo-Capitán, 2015a), the emergence of which could be considered a bottom-up phenomenon, the rest of the discursive emergences of Good Living can be considered top-down phenomena that extend from the intellectual elites in Latin American societies to the bases of social movements in the region and, in some cases, from revolutionary-style governments (Ecuador, Bolivia, Nicaragua ...) to the population sets of their respective countries.

7 This is a fight that sometimes leads to a truce, like in the case of the government of Bolivia, where noteworthy socialist intellectual leaders (e.g., García-Linera) and 'indigenist' intellectual leaders (e.g., Choquehuanca) coexist.

8 'Pachamamism' has been critically defined as a rhetorical defence of Mother Earth with abundant moral and metaphysical appeals that are ancestral (supposedly) and that impede real reflection regarding the way to conduct an authentic process of mental, economic and cultural decolonization (Rodríguez, 2011). This term tends to be used as a pejorative synonym for 'indigenism'. We advocate the use of the term 'pachamamist' as an appreciative synonym for an 'indigenist' that recognises the richness of indigenous ancestral knowledge, which adds the concept of transcendence to reason as a source of deep knowledge. 
2010; Prada, 2011; Estermann, 2012; Torrez, 2012) and Peru (Rengifo, 2002, 2010; Lajo, 2011). All of these individuals understand Good Living as living to the fullest (sumak kawsay in Kichwa, suma qamaña in Aymara or allin kawsay in Quechua) and reject the idea that modern development constitutes social aspiration (Viteri, 2003), countering that, in fact, it is merely another form of colonisation (Quijano, 2011; Prada, 2014).

These intellectuals propose recreating, in the twenty-first century, the harmonious living conditions of the indigenous peoples of Abya Yala (Latin America) (Dávalos, 2011) and propose doing so by making the so-called Andean world view (Estermann, 1998) (and other indigenous world views) the main cultural reference of Latin American societies in order to recover the ancestral identity that has been lost, and propitiate civilised change (Prada, 2011; Estermann, 2012). This conception does not prioritise achieving equity and sustainability and its influence has extended from the indigenous movements of Ecuador, Bolivia and Peru to the rest of the indigenous movements of Abya Yala, the majority of which have incorporated the concept of Good Living within their political battle cries.

This focus concedes great relevance to the self-determination of indigenous peoples by converting Latin American nation states into pluri-national states (Simbaña, 2011); there is no doubt that pluri-nationality is the ultimate purpose for which Good Living is used. Additionally, significant importance is assigned to recovering the ancestral traditions of these communities and special attention is paid to the spiritual elements of Good Living (for example, the Pachamama) (Huanacuni, 2010; Maldonado, 2010a). The majority of these tenets correspond to a pre-modern conception of the world and of the ancestral nature of the Andes and the Amazon (Hidalgo-Capitán and Cubillo-Guevara, 2014).

The intellectuals that defend this conception of Good Living are pejoratively catalogued by some intellectuals from other schools of thought as 'pachamamist' intellectuals (Stefanoni, 2010) who are trapped in an infantile discourse on 'indigenism' (Correa, 2008) and, as such, are unable to implement Good Living.

\subsection{Good Living (Socialist and Statist)}

The socialist and statist version of Good Living is derived from the neoMarxist thinking of intellectuals linked to or close to the governments of Ecuador and Bolivia (Coraggio, 2007; MPD, 2007; SENPLADES, 2009 and 2011; García-Linera, 2010; Ramírez, 2010; Páez, 2010; Patiño, 2010; Harnecker, 2010; Borón, 2010; Santos, 2010; Pomar, 2010; Houtart, 2010; Feliz, 2011; Escandell, 2011; Cárdenas, 2012; Prada-Tejada, 2012), who understand Good Living as socialism of the sumak kawsay (Ramírez, 2010) variety, Andean community socialism (García-Linera, 2010) or as an Ecuadorian or Bolivian variant of 
twenty-first century socialism and associate it with modern development in its neo-Marxist form.

These intellectuals propose implementing, through the revolutionary process known as 'the citizen revolution' in Ecuador and the 'democratic and cultural revolution' in Bolivia, a new development model that essentially aims to improve equity (Ramírez, 2010; Patiño, 2010; Harnecker, 2010)—a model that would be supported, for the moment, by 'extractivism' while a transformation is generated in the productive matrixes of Latin American countries (SENPLADES, 2012). In this scenario, the intellectuals in question relegate identity and sustainability goals to the back burner. This conception of Good Living has extended from the intellectual circles of the governments of Ecuador and Bolivia to the intellectual circles of other Left-leaning Latin American governments, which may follow Bolivarian thought or social democratic thought. The majority of these nations have included socialist and statist notions of Good Living in their political discourse.

This approach assigns great relevance to the role that the state should play in implementing Good Living (SENPLADES, 2011). In this context, the state becomes that main political agent and sole interpreter of the population's will. This has led to a scenario in which different social movements (for example, the indigenous movement and the 'ecologist' movement) that contributed to situating the concept of Good Living at the forefront of the political debate, and in the case of Ecuador and Bolivia within the constitutions, have been excluded from political activity. Proponents of this school of thought also aspire to transform Latin American socio-economic systems into post-capitalist socio-economic systems, where market economies are non-market and entities from the social and solidarity economy (Coraggio, 2007) play a leading role; in fact, post-capitalism is the final objective of this version of Good Living. The majority of these tenets correspond to a modern conception of the Western and socialist world of nature (Hidalgo-Capitán and Cubillo-Guevara, 2014).

The intellectuals who defend this conception of Good Living are seen by some intellectuals from the other two schools of thought as practitioners of senile 'developmentalism' (Martínez-Alier, 2010; Svampa, 2011) and are accused of having replaced the term 'development' in their discourse with the term Good Living, placing both concepts on the same plane, which removes Good Living from the majority of the dimensions that have been incorporated in constitutional processes (Acosta, 2015).

\subsection{Good Living ('Ecologist' and 'Post-developmentalist')}

The 'ecologist' and 'post-developmentalist' version of Good Living has adopted the 'ecologist' and 'post-developmentalist' thought of intellectuals associated 
with critics of development and with Latin American social movements (León-Trujillo, 2008, 2009; Acosta and Martinez, 2009, 2011; Tortosa, 2009, 2011;Escobar, 2009; Esteva, 2009; Carpio, 2009; Quintero, 2009; Quirola, 2009; Gudynas, 2009b, 2011a; Boff, 2009; Acosta, 2010a, 2010b, 2012; Lander, 2010; Gudynas and Acosta, 2011a, 2011b; Quijano, 2011; Svampa, 2011; Aguinaga et al., 2011; Vega, 2011, 2012), who contend that Good Living is a utopia that must be (re)built (Acosta, 2010a) or see it as the territorial manifestation of the concept of Good Living while rejecting the notion that modern development is a social aspiration, given that they consider modern development as a form of domination (Acosta, 2015).

These intellectuals propose creating local processes for social participation so that each community can define its own concept of Good Living or good co-existing by making environmental sustainability an indispensable requirement to building the said 'Good (Co)Living' (Gudynas and Acosta, 2011b). In this scenario, the need to fulfil objectives relative to equity and identity is subordinate to the need to maintain harmonious relations with nature (sustainability), which is achieved by respecting the rights of nature (Acosta and Martínez, 2011). This concept is embodied, for example, in the constitution of Ecuador, which implicitly presumes that Latin American economies will be transformed into 'post-extractivist' economies (Gudynas, 2011c). This conception of Good Living has clearly expanded among the Latin American and European ecological movements that believe that Good Living is the Latin American variation of 'de-growth', and constitutes one of many possible strategies for a socio-ecological transition (Unceta, 2014).

This approach assigns great relevance to the role that civil society, and social movements in particular (indigenous, 'ecologist', feminist, worker, peasant, pacifist, solidarity-based), should play in defining and implementing Good Living and considers these movements main political agents that should be heard and respected by Latin American governments regardless of the degree of representation that they achieve at the parliamentary level. These movements aspire to build a 'bio-centric' society where nature is at the centre of the concerns of citizens, who should be considered inseparable from the same (nature) (Gudynas, 2009b). Biocentrism is, without a doubt, the final objective of those that use Good Living in this way. The majority of these tenets correspond to a postmodern conception of the Western world (Hidalgo-Capitán and Cubillo-Guevara, 2014).

The intellectuals that defend this conception of Good Living are accused by some intellectuals from the other two schools of thought of lacking political pragmatism, being submerged in nihilism, being trapped in a discourse of romantic ecology (Correa, 2007), and of twisting the original meaning of Good Living by filling it with Western concepts that are foreign to the Andean world view (Oviedo, 2011). 
These three conceptions of Latin American Good Living did not form in a vacuum and are instead the result of the processes of reflection of numerous Latin American intellectuals, who have received many and diverse influences from other intellectuals, both from the region and from other parts of the world. Without a doubt, the adherence of each intellectual to one of these three schools of thought is directly related to the intellectual wellsprings from which they have drunk and to the amount of knowledge and number of ideas that they have absorbed from each given that some of these wellsprings are shared by two and even three of the schools of thought.

These wellsprings are very diverse. Some of the most noteworthy include $s u$ mak kawsay, suma qamaña and allin kawsay; the Andean world view; development with identity; the theory of reciprocity; post-development; the theology of liberation; the theory of dependence; the theory of 'coloniality'; sustainable development; world-system theory; human development; endogenous development; eco-socialism; twenty-first century socialism; social justice; happiness economics; the economic theory of relational goods; the social and solidarity economy; intercultural feminism; subsistence feminism; eco-feminism; the self-sufficiency economy; community economics; barefoot and human scale economics; Buddhist economics; 'post-extractivism'; 'de-growth'; deep ecology; and the theory of conviviality (Figure 3.2).

These reflections are far from unknown to the struggles of the Latin American Left for hegemony in the post-liberal era, where the main actors are indigenous movements, ecological movements and revolutionary movements with Bolivarian ${ }^{9}$ influences. These actors from the Latin American Left were at one point united against neo-liberalism and in favour of constitutional processes. It was this union that drove efforts to include Good Living as a constitutional precept in Ecuador and Bolivia. Nevertheless, since that point in time, each of the actors has tried to reinterpret the concept of Good Living to reflect its own intellectual references and political priorities. Using a genealogical perspective (Foucault, 1969), we will attempt to identify the intellectual wellsprings of each of the schools of thought of Good Living.

\subsection{The Wellsprings of 'Indigenist' and 'Pachamamist' Good Living}

The concept of Good Living, known as sumak kawsay, emerged hand in hand with indigenous intellectuals in the Amazon of Ecuador (Cubillo-Guevara and Hidalgo-Capitán, 2015a) in a context in which the notion of development held

9 Referred to the Venezuelan revolutionary thought of Hugo Chavez. 


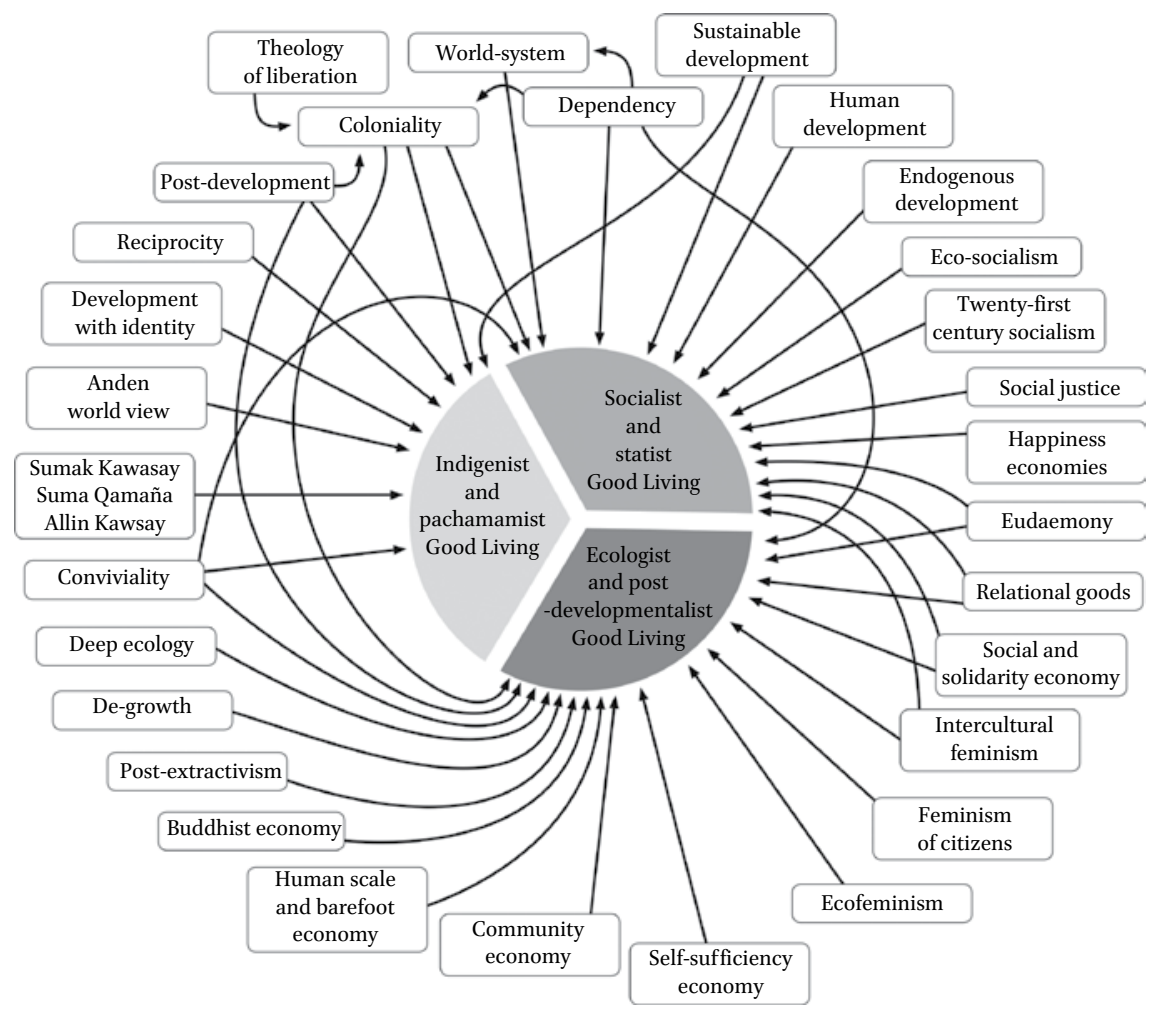

FIGURE 3.2 The intellectual wellsprings of Latin American Good Living. SOURCE: AUTHORS.

by indigenous communities in Ecuador was guided by concepts of sustainable development and development with identity. Both of these concepts were disseminated among the indigenous peoples of the Abya Yala at the end of the 1980 s by agents of international cooperation, including the World Bank, the Inter-American Development Bank (IDB) and - since 1992—by the Fund for the Development of Indigenous Peoples of Latin America and the Caribbean (FILAC) (Fondo Indígena).

Although both concepts have significant capacity to transform and are aligned with the traditional requirements of indigenous peoples, when they are reinterpreted and operationalised by cooperation agents (and in particular by the World Bank) they lose their capacity to transform and they only qualify development based on economic growth with environmental and cultural elements, in ways that lose sight of indigenous concerns. These concepts undoubtedly failed to satisfy many Latin American indigenous intellectuals, who preferred to use expressions such as 'comprehensive development' 
or 'sustainable development with identity' (Tibán, 2000). Dissatisfaction was more evident, however, with the concept of sustainable development, which included a reified conception of nature, when - for the indigenous peoples of Abya Yala — nature is a living being of which all humans are part (Silva, 2002).

Some 'indigenist' intellectuals from the Amazon began to reject all forms of adjective use ('sustainable', 'with identity', 'comprehensive'...) and proposed seeking an alternative to development rather than pursuing alternative development (Viteri, 2003). And this alternative to development emerged in 1992, the year in which - with the help of the Italian NGO Terra Nuova and the Danish NGO IBIS - the Amazanga Plan of the Organisation of Indigenous Peoples of Pastaza (OPIP) was written (Viteri et al., 1992). This constituted the first written document to include the concept of sumak kawsay, which translates as 'limpid and harmonious life'. Other documents were to follow, further exploring the concepts presented in this plan.

Without a doubt, this focus on Good Living (as a translation of sumak kawsay) was adopted by the ID B beginning in 2004 when the Kichwa anthropologist from the Amazon, Carlos Viteri, was an officer of this international body. By this date, Fondo Indígena had begun to discuss development with identity for Good Living. The emergence of sumak kawsay, and moreover its subsequent systematisation (Viteri, 2003), was clearly influenced by the foreign and native anthropologists that worked in the Amazon of Ecuador in the 1980s and 1990s, including Philippe Descola (1986), Elka Mader (1999) and Carlos Viteri (2000), who introduced the notion of post-development to this territory. The studies conducted by the Latin American Institute of Social Research (ILDIS), which is associated with the Friedrich Ebert Foundation, also played a key role in the emergence and dissemination of this concept (Acosta et al., 2000).

The indigenous intellectuals of the Amazon became aware of the fact that the modern, universalising and supposedly scientific story of development was a discursive invention of a series of Western intellectuals who used it as an instrument to exercise economic, social, political and cultural domination. This alienated the communities of countries that were considered underdeveloped (including indigenous populations) and led to a theorisation of resistance to development, and the search for alternatives, in the identity of these peoples. These intellectuals began to develop a local discourse of social transformation to achieve a future based on their day-to-day way of life, their past and their conception of the world, or world view, which they named, in accordance with their philosophy of desirable living, sumak kawsay, or a life in harmony, or Good Living. Consequently, the development of the original discourse of sumak kawsay was based on the specific world view of peoples of the Amazon. This concept represented a break from conceptions of Western 
modernity and proponents required a cultural reference point for the nonmodern alternative to development.

The genuine discourse of sumak kawsay from the Amazon was quickly assimilated by intellectuals in the Andean worlds of Ecuador, Peru and Bolivia (Kichwas, Quechuas, and Aymaras) thanks to connections between the main organisations of the indigenous movements of Ecuador (Confederation of Indigenous Nationalities of Ecuador-CONAIE), of Bolivia (Confederation of Indigenous Peoples of Bolivia- СIDOB), of Peru (Confederation of Indigenous Nationalities of Peru - CONAIP) and the Andean world in general (Andean Coordinator of Indigenous Organizations-CAOI). These organisations were very active during the 1990s, when the concept of sumak kawsay transcended the Amazon of Ecuador (Cubillo-Guevara and Hidalgo-Capitán, 2015a).

Nevertheless, there were two obstacles on the path to incorporating sumak kawsay - which translates into Quechua as allin kawsay and into Aymara as suma qamaña -into the Andean world. The first was that the Andean people's way of living in harmony had practically disappeared after five centuries of western acculturation and only a few ancestral institutions remained (minga, ayni, randi-randi ...), and the term sumak kawsay, which was void of content, was like a name stripped of meaning (Cubillo-Guevara and HidalgoCapitán, 2015a). The second obstacle was that the referential world view required for genuine sumak kawsay came from the Amazon, which, although subject to significant Andean influences, had some major differences (such as no references to the Pachamama). Undoubtedly, the incorporation of the Andean world view into the discourse of sumak kawsay, allin kawsay and suma qamaña provides a strong spiritual dimension that allows them to be positively qualified as 'pachamamist' (Cubillo-Guevara, Hidalgo-Capitán and Domínguez-Gómez, 2014).

This prompted Andean intellectuals to recreate ancestral conceptions of sumak kawsay, allin kawsay and suma qamaña based on the surviving institutions of acculturation and, moreover, on the Andean world view and Andean philosophy, or 'pachasophy'. Most definitely, the influence of the Andean world view on the 'indigenist' and 'pachamamist' conception of Good Living is felt in the 'Indianist' wing of the government of Bolivia, led by Chancellor David Choquehuanca (2010a), and in the work of Bolivian indigenous philosophers such as Simón Yampara (2001), Mario Torrez (2012) and Fernando Huanacuni (2010); also in the work of Ecuadorians indigenous philosophers such as Luis Maldonado (2010a) and Nina Pacari (2013) or Peruvians, such as Javier Lajo (2011). This conception is also reflected in the work of Bolivian 'indigenist' authors such as Javier Medina (2001, 2006, 2011), Xabier Albó (2009, 2010), Rafael Bautista (2010), Joseph Estermann (2012) or Raúl Prada (2014), or of Ecuadorians such as Atawallpa Oviedo (2011). 
To this we can add the influence of the theory of reciprocity of Dominique Temple (2003), which provided theoretical backing for the daily practices of Good Living implemented by many indigenous peoples, including those of the Andes and the Amazon. This theory explains how the Andean institutions of don - as the minga, ayni or randi-randi-contributed to creating strong bonds of community that increased the group's resilience. And with these elements, Andean indigenous and 'indigenist' intellectuals have tried to recreate the conception of desirable life that supposedly existed in the past (suma kawsay, allin kawsay or suma qamaña), which provided authentic content to what they believed to be, at first glance, a name stripped of meaning. The theory of conviviality can also be considered an important influence through which civil society, armed with ethical values, must build social living (Medina, 2006; Dávalos, 2008a).

But, in addition to these influences, we should not forget that the 'indigenist' and 'pachamamist' focus on Good Living is also based on the theory of the 'coloniality' of power, knowledge and being of the Modernity/Coloniality group. This theory contends that, given their colonial origins, both political structures and systems of knowledge, as well as the very identity of Latin American societies, prioritise the white, elite minority-descendants of the colonisers-over the groups of ethnic plurality that make up these societies and that are marginalised. As such, it is necessary to decolonise or decolonise power, knowledge and being to build intercultural and pluri-national societies. The aforementioned Modernity/Coloniality group includes intellectuals from the Latin American Left, such as Aníbal Quijano (previously associated with the theory of dependence), Enrique Dussel (previously linked with the theory of liberation) or Arturo Escobar (associated with the theory of post-development). These authors have been reference points for many 'indigenist' intellectuals who have contributed to sumak kawsay, allin kawsay or suma qamaña, as is the case of Javier Medina (2001, 2006, 2011), Pablo Dávalos (2008a, 2008b, 2011), Luis Maldonado (2010b), Xabier Albó (2009, 2010), Rafael Bautista (2010), Floresmilo Simbaña (2011) or Raul Prada (2014).

It is also important to highlight the role that European agents of international cooperation have played, who have absorbed post-development ideas and financed various studies to identify the conception of well-being (and not of development) of peoples of the Andes and the Amazon. Together with the aforementioned studies from ILDIS, some of the first studies of Good Living, such as those published by Javier Medina $(2001,2002)$ on suma qamaña and on nande reko Guaraní, were also financed by German cooperative efforts (specifically by the German government organisation GTZ), as was the publication of the works of Dominique Temple (2003) on the theory of reciprocity. Three important 'indigenist' think tanks also deserve credit. First, the Amazanga 
Institute of the Organisation of Indigenous Peoples in Pastaza in Ecuador (OPIP), which promoted the concept of sumak kawsay (Viteri et al., 1992; Viteri, 2000) and was financed by the Italian NGO Terra Nuova and the Danish entity IBIS at the beginning of the 1990s and by the European Commission at the end of the same decade. Also, the Andean Project of Peasant Technologies in Peru (PRATEC), through which Grimaldo Rengifo $(2002,2010)$ published his work on allin kawsay with funds from the Belgian foundation Broederlijk Delen and the Swiss foundation Tradition for Tomorrow. Lastly, there is the Andean Center for Agricultural Development in Bolivia (CADA), through which Simón Yampara (2001) and Mario Torrez (2001) published their initial work on suma qamaña. And we must not forget here the role played by many intellectuals associated with the Catholic Church (such as Joseph Estermann, Xabier Albó or Enrique Dussel), who contributed to the emergence, substantiation and dissemination of sumak kawsay, allin kawsay and suma qamaña, and the work conducted by educational institutions of the Church to train indigenous intellectuals from Ecuador, Bolivia and Peru.

\subsection{The Wellsprings of Socialist and Statist Good Living}

The socialist and statist version of Good Living originated after the emergence of the Movement Toward Socialism (MAS) of Evo Morales in Bolivia and of the Alliance PAIs of Rafael Correa in Ecuador, and in particular once the constitutions of each of these countries had been approved. Despite the fact that Good Living is a concept derived from the indigenous terms sumak kawsay and suma qamaña, which were promoted by the indigenous movements in Ecuador and Bolivia, the socialist governments of each country appropriated the terms, which they believed had been stripped of meaning and could be filled with content and used in the citizen revolution of Ecuador and the democratic and cultural revolution of Bolivia, respectively.

These revolutionary processes were being pushed by the Venezuelan government, in an attempt to export the model of the Bolivarian revolution led by Hugo Chávez. This model was welcomed by Rafael Correa in Ecuador and by Evo Morales (and particularly by Alvaro García-Linera) in Bolivia. In fact, the Latin American countries with governments from the revolutionary Left are grouped together in the Bolivarian Alliance for Peoples of Our America (ALBA) and include Venezuela, Cuba, Bolivia, Saint Vincent and the Grenadines, Nicaragua, Dominica, Ecuador, Antigua and Barbuda, Surinam, Saint Lucia, Granada and Saint Kitts and Nevis.

The political leaders of the Latin American revolutionary Left (such as Hugo Chávez, Evo Morales, Rafael Correa or Daniel Ortega), and the intellectuals close to them, are heirs to the neo-Marxist version of the theory of dependence and its thesis of 'stagnationism', which states that development is not possible 
under capitalism and can only be achieved by means of a national-popular revolution that allows one to initiate a transition towards socialism as a form of resistance to capitalist globalisation and as method through which to disconnect from the capitalist world-system.

These individuals do not reject the concept of development, as the 'indigenist' and the 'post-developmentalist' intellectuals do; rather, they seek alternative development. In this context, and before the constitutions were approved in Bolivia and Ecuador, Evo Morales and Rafael Correa, during their first terms, followed neo-Marxist, 'structuralist' and dependency influences to focus their development policies on concepts of human development, sustainable development, endogenous development (this had also been advocated by the government of Hugo Chávez in Venezuela) and development with identity, as a way to achieve Good Living (MPD, 2007; SEN P LADES, 2007). These individuals assume that alternative development is at the service of Good Living rather than positing that Good Living is an alternative to development. For this reason, the proposals of these governments, with regard to Good Living, are seen by critics as being developmentalist.

Nevertheless, to endow Good Living with contents that are better aligned with the revolutionary processes of both countries and inspired by the Venezuelan Bolivarian revolution, some well-known intellectuals and politicians of both governments began to develop Ecuadorian and Bolivian variations of twenty-first century socialism. This proposal, which originated in Latin America and was appropriated to act as the theoretical basis for Hugo Chávez's policies, is based on the idea that socialism should be built by grassroots organisations, which should drive a participative democracy that seeks to achieve development through an economy in which a product's value is determined by production time rather than the market.

This proposal was adapted to the Ecuadorian reality by the National Secretary of Planning in Ecuador, René Ramírez (2010), under the name 'socialism of sumak kawsay' (or 'republican bio-socialism') and by the vice president of Bolivia, Alvaro García-Linera (2010), under the name 'Andean community socialism' (or 'community socialism for Good Living'). These adaptations were influenced by the theory of 'coloniality' in that the theory advocates the 'de-coloniality' of power so that the indigenous populations of Ecuador and Bolivia, as oppressed peasants, can gain access to national spaces of power and representation and to ensure that the cultural peculiarities of the indigenous peoples of each country are taken into consideration.

These governments also set up meetings and promoted publications that studied the relation between Good Living and socialism. Various well-known intellectuals of the Latin American Left participated in these efforts, including 
the Ecuadorians René Ramírez (2010) and Ricardo Patiño (2010), the Bolivians Felix Cárdenas (2012) and María Nela Prada-Tejada (2012), the Chilean Marta Harnecker (2010, 2011), the Argentinians José Luis Coraggio (2007), Atilio Borón (2010 and 2012) and Mariano Feliz (2011), the Cuban Vicente Escandell (2011), and members of the European Left such as Francois Houtart (2010), the Portuguese Boaventura de Sousa Santos $(2010)^{10}$ or the (Spanish) Basque Katu Arkonada (2012). Some of these intellectuals have been linked with one of the most important academic networks of the Latin American Left-the Latin American Council of Social Sciences (CLACSO), noteworthy members of which include Atilio Borón, René Ramírez and Alvaro García-Linera.

Eco-socialism has also influenced the socialist and statist version of Good Living. This school of thought contends that capitalism is as dangerous for society as it is for nature and advocates a socio-ecological transition to a biocentric and post-capitalist society. This would fit very well with the republican bio-socialist proposal for Good Living (Ramírez, 2010) or the work on the dialogue between eco-socialism and Good Living that was published by the Institute of National Higher Education (IAEN) in Ecuador (Le Quang and Vercoutere, 2013).

In the quest to build a post-capitalist society it is also important to highlight, along with the influences of different schools of neo-Marxist socialist thought, the school of thought relative to the social and solidarity (or popular and solidarity) economy, with its maxim of 'an economy with a market, not a market economy', which although compatible with twenty-first century socialism is also aligned with an economy that is neither capitalist nor socialist, meaning an economy in which private national companies and transnational companies (for profit), national public companies and grand-nationals companies $^{11}$ (with public service purposes), cooperatives companies, social integration companies and family businesses (with socio-economic ends) and foundations and volunteer associations (with social and solidarity ends) co-exist (Coraggio, 2007; Ramírez, 2010).

Nevertheless, in praxis, different versions of Good Living and variations of twenty-first century socialism, particularly in a socialist economy, can be categorised as variations of twenty-first century capitalism or of authoritarian or 'developmentalist' state capitalism. At the praxis level, these versions have also distanced themselves from the theory of 'coloniality' given that although

\footnotetext{
10 Boaventura de Sousa Santos and François Houtart have made noteworthy contributions to both 'post-developmentalist' Good Living and socialist Good Living.

11 A grand-national company is a transnational company whose social capital is the property of several governments.
} 
they have attempted to integrate indigenous peoples and afro-descendants into the spheres of national policy ('de-coloniality' of power) and-to a certain extent-have brought the contribution of indigenous peoples to the national identity to the forefront, they have been reticent to accept an authentic 'de-coloniality' of knowledge and, as such, continue to impose a conception of the world that is based on modernity with a socialist or neo-Marxist orientation. And, of course, these versions have also distanced themselves from bio-centrism and the search for harmony with nature, by implementing 'extractivist' policies for development in the pursuit of equity that were supposedly temporary and in place only until the transformation of the national productive matrix was complete. The conception of the social and solidarity economy has been somewhat more successful.

The following have more than likely influenced this school of thought of Good Living: the Rawlsiana school of social justice, which is based on ideas of justice and equity (Ramírez, 2010); the theory of conviviality, which posits that civil society, armed with ethical values, should build social living (Le Quang and Vercoutere, 2013); Aristotelian eudaemony, where happiness can only be achieved through ethical behaviour (Ramírez, 2010); intercultural feminism, with its concepts of 'de-coloniality' and the 'de-patriarchalisation' of power (Romero and Lanza, 2012; Mamani, 2012); or relational goods economics, which seeks to 'de-mercantalise' and 'de-materialise' consumption (Ramírez, 2010).

In an attempt to operationalise socialist and statist Good Living, some authors are promoting the search for indicators that can measure the level of national Good Living, for which they turn to progress in the field of happiness economics and, in particular, to subjective measurements of well-being (Ramírez, 2009; León-Guzmán, 2015).

\subsection{The Wellsprings of 'Ecologist' and 'Post-developmentalist' Good Living}

The influence of post-development is a key to understanding the ecologicalist and post-developmentalist conception of Good Living. This influence was highly evident in the configuration of the concept of Good Living that was included in the constitution of Ecuador of 2008; in fact, this school of thought originated in the constitutional debates that took place in Ecuador in the years 2007 and $2008 .^{12}$

12 In the case of the constituent process in Bolivia, there was also a high level of citizen participation in debates regarding Good Living; these discussions were fundamentally influenced by two schools of thought —-indianism' and socialism. 
When some assembly members linked with the 'indigenist' party Pachakutik proposed incorporating sumak kawsay in the Ecuadorian constitution (Cubillo-Guevara and Hidalgo-Capitán, 2015a), the members of the ruling party, Alliance PAIs, led by the president of the assembly, Alberto Acosta, accepted the term, translated as Good Living, given that as a term stripped of meaning, it could be filled with content via a participatory process. As such, the Constitutional Assembly of Ecuador, under the presidency of Alberto Acosta, became a forum for reflection on Good Living. ${ }^{13}$

This assembly was advised by local intellectuals (such as the 'indigenists' Pablo Dávalos, Pablo Ortiz and Nina Pacari, the feminist Magdalena León, the 'ecologists' Esperanza Martínez and Dania Quirola, the 'post-developmentalist' Patricio Carpio and the 'de-colonialist' Edward Vargas) and foreign intellectuals (such as the 'de-colonialists' Aníbal Quijano, Boaventura de Sousa Santos and Edgardo Lander, the 'ecologists' Eduardo Gudynas and Antonio Elizalde and the socialists François Houtart and Vicente Martínez-Dalmau), while other noteworthy Ecuadorian intellectuals (such as the 'indigenists' Pedro Morales, Mónica Chuji, the socialists Norman Wray and Virgilio Hernández, the 'ecologist' and socialist Alberto Acosta and the theologian Fernando Vega), participated as assembly members and were linked with different schools of thought. All of this generated a collage concept of Good Living in the Ecuadorian constitution that was a hybrid of very different conceptions. ${ }^{14}$

Undoubtedly, the fact that Good Living is frequently referred to as a 'utopia to be built' reflects its status as a collage construct, although the post-development influence is also manifest both in direct references to Good Living as a concept that is on the path of post-development, which entails dissolving the idea of progress that goes beyond development, or as an alternative to development, and in its negation of Good Living, as a universal concept and in its defence of 'Good Coexistences' (Buenos Convivires), which is borne of a community construction that will vary from one territory to the next. In addition, noteworthy post-development authors, such as Arturo Escobar (2009) and Gustavo Esteva (2009), have written about Good Living.

Here the links between the political and intellectual leaders of the Ecuadorian Constituent Assembly (including Alberto Acosta, Fernando Vega, Virgilio Hernández, Norman Wray, Pedro Morales and Mónica Chuji), with alternative social movements in Ecuador (particularly 'ecologist', indigenous, worker,

\footnotetext{
13 Something similar occurred during the Bolivian constituent process but the international impact was less significant.

14 Including, although to a lesser degree, the Bolivian constitutional concept of Vivir Bien/ Living Well.
} 
peasant, feminist, and theology of liberation groups) and Latin America (most notably the Global Social Forum, whose ranks include a number of intellectuals with clear tendencies in this regard—such as François Houtart, Arturo Escobar, Gustavo Esteva, Edgardo Lander, Boaventura de Sousa Santos, Catherine Walsh, Leonardo Boff and Aníbal Quijano), have been crucial. In fact, the maxim of alter-globalisation - that 'another world is possible' - has led to the idea that 'other development is possible', which is defended by the Latin American Alliance of Critical Studies on Development (ALECD), whose coordinating committee is comprised of well-known intellectuals from the Global Social Forum and noteworthy authors writing on the subject of ecological and post-development Good Living (Alberto Acosta, Arturo Escobar, Gustavo Esteva, Eduardo Gudynas, Edgardo Lander, Enrique Leff, Koldo Unceta and Maristella Svampa).

But in the 'ecologist' and 'post-developmentalist' conception of Good Living, influences from the theory of 'coloniality' (with its denouncement of structural racism in Latin American societies and its proposals to 'de-colonialise' power, knowledge and being), the theory of dependence (with its denouncement of the social inequalities stemming from the international insertion of Latin American economies), and liberation theology (with its preferential option for the poor) have been fundamental. A number of noteworthy authors have written about Good Living, including intellectuals that have studied the theory of dependence, such as Aníbal Quijano (2011); liberation theology, such as Leonardo Boff (2009), François Houtart (2011) and Fernando Vega (2012); and, most importantly, those associated with the theory of 'coloniality', such as Boaventura de Sousa Santos (2009), Edgardo Lander (2010), Catherine Walsh (2009 and 2010) and Aníbal Quijano (2011). In addition to these individuals, among the assembly's members, there were some Ecuadorian intellectuals who were clearly influenced by liberation theology, including Pedro Morales and Fernando Vega, and there were other intellectuals influenced by the theory of 'coloniality', such as Virgilio Hernández and Alberto Acosta. The vast majority of the assembly members from the ruling party, Alliance PAIs, were influenced by dependency theory.

Of the three versions of Good Living, the ecologist and post-developmentalist perspective has enjoyed the most international exposure, clearly transcending Andean and Latin American ambits with noteworthy contributions from European authors such as the Spaniards Jose María Tortosa $(2009,2011)$ and Koldo Unceta (2014), the Portuguese Boaventura de Sousa Santos (2009) and the Belgian François Houtart (2013), particularly from the ambit of academia. This has provided a high degree of intellectual legitimacy, which has even led to a twinning between Latin American Good Living and European 'degrowth' (Unceta, 2014; Cubillo-Guevara and Hidalgo-Capitán, 2015b). In the 
Andean context, one of the main financers of publications on 'ecologist' and 'post-developmentalist' Good Living has been the German Rosa Luxemburg Foundation, whose Andean headquarters has links to, among others, Alberto Acosta, Eduardo Gudynas, Maristella Svampa, Esperanza Martínez, Edgardo Lander, Margarita Aguinaga and Koldo Unceta.

But this version of Good Living has been mainly influenced by the ecologist movement. Authors of works on Good Living include well-known Latin American 'ecologists', such as Eduardo Gudynas, Alberto Acosta o Esperanza Martínez. In addition, one of the main intellectual forces of 'ecologism' in Latin America, in terms of Good Living, has been the Latin American Center for Social Ecology (CLAES), an 'ecologist' think tank headquartered in Uruguay (and directed by Eduardo Gudynas) and directly linked with ALECD; in the Ecuadorian case, the main 'ecologist' body linked to this conception of Good Living is Ecological Action, presided over by Esperanza Martínez.

The main influence of the 'ecologist' version of Good Living is without doubt deep ecology, from which the concept of 'bio-centrism' is derived, and which is an element of the 'ecologist' version of Good Living (Gudynas, 2009b). This concept refers to a conception of the world in which nature is the sum of all things and possesses an intrinsic value that is independent of the utility that things have for human beings; accordingly, rights of nature should be recognised. The Gaia hypothesis, which posits that life creates and maintains the conditions adequate for its existence, is also closely related to deep ecology. Under this hypothesis, Earth is a system that is capable of self-regulation and 'autopoiesis'. This conception is very similar to that of the Pachamama, or Mother Earth, from the Andean world view, which is also used by some authors that adhere to the ecological version of Good Living (Boff, 2009; Martínez, 2010).

The second major ecological influence of Good Living is the 'postextractivist' proposal, which was developed by ClaEs. 'Post-extractivism' criticises 'extractivism' as a development model and proposes initiating processes to transition towards models of development that imply the lowest environmental impact possible ${ }^{15}$ and that are geared towards ensuring that the smallest amounts of natural resources possible are extracted, thus guaranteeing the harmonious subsistence of the human race within nature, which fits very well with the ecological and post-development conception of Good Living (Gudynas, 2009a, 2011b, 2013; Acosta, Martínez and Sacher, 2013).

The third major influence on Good Living has been 'de-growth', which is based on the idea that we do not need to produce and consume more to live better. This idea has been fundamental to the 'ecologists' Good Living argument that, for development's sake, the exploitation of natural resources (oil,

15 Including the impact on the climate (Honty and Gudynas, 2014). 
water, wood, biodiversity) should be renounced, and that we should move towards prioritising resource conservation over the generation of economic benefit (Acosta et al., 2009; López-Flores, 2014).

As a collage of diverse intellectual contributions, ecologist and postdevelopmentalist Good Living has also been influenced by the Latin American feminist movement, which was articulated in the framework of the Latin American and Caribbean Feminist Encounters (1981-2014). This movement has helped channel the influences of eco-feminism, intercultural feminism and subsistence feminism into Good Living. In this context, some of the ideas of eco-feminism, such as the belief that women have a more intimate relationship with nature given that they are responsible for economic activities relative to subsistence, fit very well with the concept of harmony with nature as proposed in Good Living (Aguinaga, 2010). The same can be said for some of the ideas of intercultural feminism, such as 'de-coloniality' and the 'de-patriarchalisation' of power, knowledge and being (Vega, 2011); subsistence feminism (or subsistence economics); or the social and economic recognition of productive and reproductive work and that both must be done in under equal conditions (León-Trujillo, 2009).

Within the ambit of economics, and with regard to a strategy for creating a post-capitalist society, the concept of the social and solidarity economythe maxim of which is 'economics with a market, not market economics'exercises an even more relevant influence than does subsistence economics on the concept of Good Living, serving to inspire the concept's economic dimension. The Latin American movement for the social and solidarity economy, which is comprised primarily of cooperatives, family businesses and private volunteer organisations, comes together in the Latin American and Caribbean section of the Inter-Continental Network for the Promotion of Social Solidarity Economy. Without a doubt, the social and solidarity economy has become the main economic rationale for ecological and post-development Good Living, given that it contributes to achieving equity, is participative in nature, and due to its smaller scale, tends to generate negative environmental impacts (Acosta, 2010b; Razeto, 2012; Unceta, 2014).

Along these lines, it is important to consider indigenous community economics among the references for ecologist and post-developmentalist Good Living. The concept is based on the maxims of self-sufficiency and solidarity, which means obtaining from nature that which is necessary to subsist, and sharing these resources in a community fashion (Mutuberria and Solano, 2011). This resonates with Gandhian self-sufficiency, which rejects importing goods that can be produced locally, thus generating a considerable positive impact on local sectors, employment and consumption (Acosta, 2010b); with Buddhist economics, which, in accordance with its maxim 'small is beautiful', defends 
the quest to establish harmony, a simple life and small-scale economic activities (Tortosa, 2011); with barefoot and human-scale economics, which focus on satisfying human needs rather than human anxieties (Acosta, 2015); with the economic theory of relational goods, which advocates the 'de-mercantilisation' and 'de-materialisation' of consumption (Unceta, 2014); with the theory of conviviality, under which civil society, armed with ethical values, must build a social living (Acosta, 2010b); and with Aristotelian eudaemony, which rejects the notion that a full life or happiness can be achieved through riches, fame or pleasure and defends only that which can be achieved through virtue, meaning that virtue is coherent with ethical values (Acosta, 2015).

\section{Conclusions}

In this chapter we have established, through a deconstruction of the concept, that Latin American Good Living - as a way of living in harmony with oneself (identity), with society (equity) and with nature (sustainability) - has three different versions: one that is 'indigenist' and 'pachamamist', which prioritises identity to build a pluri-national society; another that is socialist and statist, which prioritises equity to build a post-capitalist society; and the last, which is 'ecologist' and 'post-developmentalist', which prioritises sustainability to build a 'bio-centric' society. This has led us to the conclusion that each of these versions can be identified within discourses on development with identity, development with equity and sustainable development. Nonetheless, this conclusion is questionable given that some of these conceptions deny the validity of any kind of development. But, if we understand Good Living in a comprehensive and synthesised manner, we find that the concept is embodied in a new discourse that is different from its predecessors and is trans-developmental and trans-modern in nature.

We have also found that Good Living has different intellectual origins, such as sumak kawsay, suma qamaña and allin kawsay; the Andean world view; development with identify; the theory of reciprocity; post-development; the theology of liberation; the theory of dependence; the theory of 'coloniality'; sustainable development; world-system theory; human development; endogenous development; eco-socialism; twenty-first century socialism; social justice; happiness economics; eudaemony; the economic theory of relational goods; the social and solidarity economy; intercultural feminism; subsistence feminism; eco-feminism; the self-sufficiency economy; community economics; barefoot and human scale economics; Buddhist economics; 'post-extractivism'; 'de-growth'; deep ecology; and the theory of conviviality. And this allows us to conclude that if Good Living emerged from the dissatisfaction of 'indigenist' 
intellectuals with different versions of development, this concept would not have achieved the relevance it currently boasts if agents of international cooperation, the governments of Ecuador and Bolivia and their constitutional assemblies, Latin American social movements and Latin American (and European) academics had not adopted it and contributed to expanding its content beyond the parameters established in the original indigenous version. As such, the trinity of Good Living has become the most innovative and highpotential concept in the field of political economy of development.

\section{References}

Acosta, A. (2015) 'El Buen Vivir como alternativa al desarrollo', Revista Políticay Sociedad, 52(2), pp. 299-330.

Acosta, A. (2013) 'Construir el buen vivir — sumak kawsay', Lalíneadefuego.info, 08/o1, https://lalineadefuego.info/2013/o1/o8/construir-el-buen-vivir-sumak-kawsay-por -alberto-acosta/ (accessed on 14 October 2016).

Acosta, A. (2012) Buen Vivir / Sumak Kawsay (Quito: Abya Yala).

Acosta, A. (2010a) 'El Buen (con) Vivir, una utopía por (re)construir', in A. Guillén (ed.) Retos del Buen Vivir (Cuenca: PYDLOS), pp. 21-52.

Acosta, A. (2010b) El Buen Vivir en el camino del post-desarrollo. Una lectura desde la Constitución de Montecristi (Quito: Fundación Friedrich Ebert).

Acosta, A. and E. Martínez (eds.) (2011) La naturaleza con derechos (Quito: Abya Yala). Acosta, A. and E. Martínez (eds.) (2009) El Buen Vivir (Quito: Abya Yala).

Acosta, A., E. Martínez and W. Sacher (2013) 'Salir del extractivismo', in M. Lang et al. (eds.) Alternativas al capitalismo/colonialismo del siglo XXI (Quito: Fundación Rosa Luxemburg).

Acosta, A., E. Gudynas, E. Martínez and J. Vogel (2009) 'Dejar el crudo en tierra o la búsqueda del paraíso perdido. Elementos para una propuesta política y económica para la Iniciativa de no explotación del crudo del ITT', Revista Polis, 23, pp. 429-452.

Acosta, A. et al. (200o) El Ecuador post-petrolero (Quito: Oilwatch, Acción Ecológica, ILDIS).

Aguinaga, M. (2010) 'Ecofeminismo: mujer y Pachamama, no solo es posible una crítica al capitalismo y al patriarcado', $A L A I, 14 / 07$, http://www.alainet.org/es/active/39531 (accessed on 14 October 2016).

Aguinaga, M., M. Lang, D. Monkrani and A. Santillana (2011) 'Pensar en el feminismo', in M. Lang and D. Monkrani (eds.) Más allá del desarrollo (Quito: Fundación Rosa Luxemburg), pp. 55-82.

Albó, X. (2010) 'Suma Qamaña, Convivir Bien. ¿Cómo medirlo?', Diálogos, 1(o), pp. 54-64.

Albó, X. (2009) Suma qamaña = el buen convivir (La Paz: CIPCA). 
Arkonada, K. (2012) 'Propuestas para la transición', in K. Arkonada (ed.) Transiciones hacia el Vivir Bien (La Paz: Ministerio de Culturas).

Bautista, R. (2010) Hacia una constitución del sentido significativo del vivir bien (La Paz: Rincón Ediciones).

Boff, L. (2009) ‘¿Vivir mejor o el Buen Vivir?', ALAI, 30/o3, http://www.alainet.org/es/ active/29839 (accessed on 14 October 2016).

Borón, A. (2012) América Latina en la geopolítica del imperialismo (Buenos Aires: Ediciones Luxemburg).

Borón, A. (2010) 'El socialismo del siglo XXI', in SENPLADES Socialismo y Sumak Kawsay (Quito: SENPLADES), pp. 109-131.

Cárdenas, F. (2012) 'Bolivia vive un proceso histórico', in K. Arkonada (ed.) Transiciones al Vivir Bien (La Paz: Ministerio de Culturas), pp. 11-16.

Carpio, P. (2009) 'El Buen Vivir, más allá del desarrollo', in A. Acosta and E. Martínez (eds.) El Buen Vivir (Quito, Abya Yala), pp. 115-148.

Choquehuanca, D. (2010a) 'El Buen Vivir / Suma Qamaña', La Razón, o3/o2.

Choquehuanca, D. (2010b) 'Hacia la reconstrucción del Buen Vivir', América Latina en Movimiento, 452, pp. 8-13.

Coraggio, J.L. (2007) 'La economía social y la búsqueda de un programa socialista para el siglo XXI', Foro, 62, pp. 37-54.

Correa, R. (2008) Intervención del Presidente de la República, Rafael Correa, pronunciado en la ceremonia de clausura de la Asamblea Constituyente (Montecristi: 25/07).

Correa, R. (2007) Discurso del Presidente de la República, Rafael Correa, sobre el levantamiento en Dayuma (Orellana: 01/12).

Cortez, D. (2009) 'La construcción social del Buen Vivir (Sumak Kawsay) en Ecuador', in Ewha Womans University (ed.) Proceedings of Congress for Intercultural Philosophy, 8 (Seúl: 03/o6).

Cubillo-Guevara, A.P. and A.L. Hidalgo-Capitán (2015a) 'El sumak kawsay genuino como fenómeno social amazónico ecuatoriano', Obets, 10(2), pp. 301-333.

Cubillo-Guevara, A.P. and A.L. Hidalgo-Capitán (2015b) 'El trans-desarrollo como manifestación de la trans-modernidad', Revista de Economía Mundial, 41, pp. 127-158.

Cubillo-Guevara, A.P., A.L. Hidalgo-Capitán and J.A. Domínguez Gómez (2014) 'El pensamiento sobre el buen vivir', Reforma y Democracia, 6o, pp. 27-58.

Dávalos, P. (2011) 'Sumak Kawsay (La Vida en Plenitud)', in S. Álvarez (ed.) Convivir para perdurar (Barcelona: Icaria), pp. 201-214.

Dávalos, P. (2008a) 'El Sumak Kawsay (Buen Vivir) y las cesuras del desarrollo', Boletín ICCI, 10-111, http://icci.nativeweb.org/boletin/111/davalos.html (accessed on 14 October 2016).

Dávalos, P. (2008b) 'Reflexiones sobre el Sumak Kawsay (el Buen Vivir) y las teorías del desarrollo', Boletín ICCI, 10-113, http://pacha.me/blog/reflexiones-sobre-el-sumak -kawsay-el-buen-vivir-y-las-teorias-del-desarrollo (accessed on 14 October 2016).

Derrida, J. (1967) Of Grammatology (Baltimore: John Hopkins University Press, 1997). 
Descola, P. (1986) La selva culta. Simbolismo y praxis en la ecología de los achuar (Quito: Abya Yala, 1996).

Escandell, V. (2011) 'Vivir Bien, ALBA y Socialismo del Siglo XXI', in I. Farah and L. Vasapollo (eds.) Vivir bien: ¿paradigma no capitalista? (La Paz: DIDES-UMSA), pp. 311-319.

Escobar, A. (2009) 'Una minga para el posdesarrollo', América Latina en Movimiento, 445 , pp. $26-30$.

Estermann, J. (2012) 'Crisis civilizatoria y Vivir Bien', Polis, 33.

Estermann, J. (1998) Filosofía andina (Quito: Abya Yala).

Esteva, G. (2009) 'Más allá del desarrollo: la buena vida', América Latina en Movimiento, 445, pp. $1-5$.

Féliz, M. (2011) 'El fundamento de la política del vivir bien', in I. Farah and L. Vasapollo (eds.) Vivir bien: ¿paradigma no capitalista? (La Paz: DIDES-UMSA), pp. 169-185.

Foucault, M. (1969) La Arqueología del Saber (México: Siglo XXI, 1987).

García-Linera, Á. (2010) 'El Socialismo Comunitario. Un aporte de Bolivia al mundo', Revista de Análisis. Reflexiones sobre la coyuntura, 5(3).

Gudynas, E. (2013) 'Extracciones, extractivismos y extrahecciones. Un marco conceptual sobre la apropiación de recursos naturales', Observatorio del Desarrollo, 18, http://ambiental.net/wp-content/uploads/2015/12/GudynasApropiacionExtractivismoExtraheccionesOdeD2013.pdf (accessed on 14 October 2016).

Gudynas, E. (2011a) 'Buen Vivir. Germinando alternativas al desarrollo', América Latina en Movimiento, 462, pp. 1-20.

Gudynas, E. (2011b) 'Caminos para las transiciones post-extractivistas', in A. Alayza and E. Gudynas (eds.) Transiciones. Post extractivismo y alternativas al extractivismo en el Perú (Lima: RedGE and CEPES), pp. 187-216.

Gudynas, E. (2011c) 'Desarrollo, postextractivismo y buen vivir', Pueblos, 49, pp. 19-21.

Gudynas, E. (2009a) 'El Buen Vivir más allá del extractivismo', in A. Acosta (ed.) La maldición de la abundancia (Quito: Abya Yala), pp. 15-20.

Gudynas, E. (2009b) 'La dimensión ecológica del Buen Vivir: entre el fantasma de la modernidad y el desafío biocéntrico', Obets, 4, pp. 49-53.

Gudynas, E. and A. Acosta (2011a) 'El Buen Vivir más allá del desarrollo', Qué Hacer, 181, pp. $70-81$.

Gudynas, E. and A. Acosta (2011b) 'La renovación de la crítica al desarrollo y el Buen Vivir como alternativa', Utopía y Praxis Latinoamericana, 53, pp. 71-83.

Harnecker, M. (2011) 'Ecuador. Una nueva izquierda en búsqueda de la vida en plenitud' (Quito: Abya Yala).

Harnecker, M. (2010) 'El nuevo modelo económico del socialismo del siglo XXI', in SENPLADES Socialismo y Sumak Kawsay (Quito: SENPLADES), pp. 77-89.

Hidalgo-Capitán, A.L. and A.P. Cubillo-Guevara (2015) 'La Trinidad del Buen Vivir en Ecuador', Política Exterior. Latinoamérica Análisis, 14/og, http://www.politicaexterior 
.com/latinoamerica-analisis/la-trinidad-del-buen-vivir-en-ecuador/ (accessed on 14 October 2016).

Hidalgo-Capitán, A.L. and A.P. Cubillo-Guevara (2014) 'Seis debates abiertos sobre el sumak kawsay', Íconos, 48, pp. 25-40.

Honty, G. and E. Gudynas (2014) Cambio climático y transiciones al buen vivir (Lima: CLAES).

Houtart, F. (2013) El bien común de la humanidad, Cuadernos Subversivos 7 (Quito: IAEN).

Houtart, F. (2011) 'El concepto de Sumak Kawsay (Buen Vivir) y su correspondencia con el bien común de la humanidad', Ecuador Debate, 84, pp. 57-76.

Houtart, F. (2010) 'La crisis del modelo de desarrollo y la filosofía del sumak kawsay', in SENPLADES Socialismo y Sumak Kawsay (Quito: SENPLADES), pp. 91-97.

Huanacuni, F. (2010) Buen Vivir / Vivir Bien (Lima: CAOI).

Lajo, J. (2011) 'Un modelo sumaq kawsay de gobierno', Voltairenet.org. Páginas Libres, 29/o8, http://www.voltairenet.org/article171245.html (accessed on 14 October 2016).

Lander, E. (2010) 'Estamos viviendo una profunda crisis civilizatoria', América Latina en Movimiento, 452, pp. 1-3.

Le Quang, M. and T. Vercoutère (2013) Ecosocialismo y Buen Vivir (Quito: IAEN).

León-Guzmán, M. (2015) Del discurso a la medición. Propuesta metodológica para medir el Buen Vivir en Ecuador (Quito: INEC).

León-Trujillo, M. (2009) 'Cambiar la economía para cambiar la vida', in A. Acosta and E. Martínez (eds.) El Buen Vivir (Quito: Abya Yala), pp. 63-74.

León-Trujillo, M. (2008) 'Después el “desarrollo": el "buen vivir” y las perspectivas feministas para otro modelo en América Latina', Umbrales, 18, pp. 35-44.

López-Flores, P. (2014) 'Neo-extractivismo y Vivir Bien en Bolivia', Alter-nativa, 1, pp. $29-44$.

Macas, L. (2010) 'Sumak Kawsay. La vida en plenitud', América Latina en Movimiento, 452, pp. 14-16.

Mader, E. (1999) Metamorfosis del poder. Persona, mito y visión en la sociedad de Shuar y Achuar (Quito: Abya Yala).

Maldonado, L. (2010a) 'El sumak kawsay/Buen Vivir/Vivir Bien', in A.L. HidalgoCapitán, A. Guillén and N. Deleg (eds.) Sumak Kawsay Yuyay (Huelva, España: CIM and PYDLOS), pp. 193-210.

Maldonado, L. (2010b) 'Interculturalidad y Buen Vivir en el marco de las políticas públicas', in A.L. Hidalgo-Capitán, A. Guillén and N. Deleg (eds.) Sumak Kawsay Yuyay (Huelva, España: CIM and PYDLOS), pp. 211-220.

Mamani, A. (2012) 'La despatriarcalización entre momento constituyente y momento constitutivo', in K. Arkonada (ed.) Transiciones al Vivir Bien (La Paz: Ministerio de Culturas), pp. $65^{-78 .}$ 
Martínez, E. (2010) ‘Pachamama y Suma Kawsay’, in Universidad Andina Simón Bolívar (ed.) Simposio Latinoamericano Pachamama, pueblos, liberación y Sumak Kawsay (Quito: 27-29/01), http://www.sicsal.net/reflexiones/CentenarioProanhoEMartinez.pdf (accessed on 14 October 2016).

Martínez-Alier, J. (2010) 'No sé si hay un ecologismo infantil pero sí creo que hay un desarrollismo senil', Le Monde Diplomatique, 14/o2, http://www.rebelion.org/noticia .php?id=100428 (accessed on 14 October 2016).

Medina, J. (2011) ‘Acerca del Suma Qamaña', in I. Farah and L. Vasapollo (eds.) Vivir bien: ¿paradigma no capitalista? (La Paz: DIDES-UMSA), pp. 39-65.

Medina, J. (ed.) (2006) Suma Qamaña, por una convivialidad postindustrial (La Paz: Garza Azul Editores).

Medina, J. (ed.) (2002) Ñande Reko. La comprensión guaraní de la vida buena (La Paz: GTZ).

Medina, J. (ed.) (2001) Suma Qamaña. La comprensión indígena de la vida buena, Serie Gestión Pública Intercultural (GPI) (La Paz: GTZ).

MPD (Ministerio de Planificación del Desarrollo) (2007) Plan Nacional de Desarrollo 2007-2011 (La Paz: MPD).

Mutuberría, V. and H. Solano (2011) 'Perspectivas y aportes desde la Economía Comunitaria como alternativa para el desarrollo de "otra economía” en Latinoamérica', Estudios de Economía Política y Sistema Mundial, 11, http://www.centrocultural.coop/ revista/articulo/211/perspectivas_y_aportes_desde_la_economia_comunitaria _como_alternativa_para_el_desarrollo_de_\%93otra_economia\%94_en_latinoamerica.html (accessed on 14 October 2016).

Oviedo, A. (2011) Qué es el Sumakawsay. Más allá del capitalismo y del socialismo (Quito: Ediciones Sumak).

Pacari, N. (2013) 'Sumak Kawsay para que tengamos vida', in A.L. Hidalgo-Capitán, A. Guillén and N. Deleg (eds.) Sumak Kawsay Yuyay (Huelva, España: CIM, PYDLOS, 2014), pp. 343-356.

Páez, P. (2010) 'Crisis, nueva arquitectura financiera y Buen Vivir', in SENPLADES (ed.) Socialismo y Sumak Kawsay (Quito: SENPLADES), pp. 189-198.

Patiño, R. (2010) 'Diferencias entre el socialismo del siglo XX y el socialismo del siglo XXI', in SENPLADES (ed.) Socialismo y Sumak Kawsay (Quito: SENPLADES), pp. 133-140.

Pomar, V. (2010) 'Algunas ideas sobre la lucha por el socialismo en el siglo XXI', in SENPLADES (ed.) Socialismo y Sumak Kawsay (Quito, SENPLADES), pp. 141-146.

Prada, R. (2014) Descolonización y transición (Quito: Abya Yala).

Prada, R. (2011) 'El vivir bien como alternativa civilizatoria', in M. Lang and D. Monkrani (eds.) Más allá del desarrollo (Quito: Abya Yala), pp. 227-256.

Prada-Tejada, M.N. (2012) 'El diálogo del socialismo con el Vivir Bien', in K. Arkonada (ed.) Transiciones al Vivir Bien (La Paz: Ministerio de Culturas), pp. 221-238. 
Quijano, A. (2011) 'Bien Vivir: entre el desarrollo y la des/colonialidad del poder', Ecuador Debate, 84, pp. 77-88.

Quintero, R. (2009) 'Las innovaciones conceptuales de la Constitución de 2008 y el Sumak Kawsay', in A. Acosta and E. Martínez (eds.) El Buen Vivir (Quito: Abya Yala), pp. $75^{-91 .}$

Quirola, D. (2009) 'Sumak Kawsay. Hacia un nuevo pacto social en armonía con la naturaleza', in A. Acosta and E. Martínez (eds.) El Buen Vivir (Quito: Abya Yala), pp. 103-114.

Ramírez, R. (2010) Socialismo del Sumak Kawsay o biosocialismo republicano (Quito: SENPLADES).

Ramírez, R. (2009) La Felicidad como Medida del Buen Vivir en Ecuador. Entre la materialidady la subjetividad (Quito: SENPLADES).

Razeto, L. (2012) 'Economía Solidaria para una Vida Nueva, para un Buen Vivir', in Escuela Politécnica Nacional (ed.) Actas del VI Encuentro Nacional de RENAFIPSE (Quito: 22-24/11), http://www.luisrazeto.net/content/econom\%C3\%ADa-solidariapara-una-vida-nueva-para-un-buen-vivir (accessed on 14 October 2016).

Rengifo, G. (2010) Los Watunakuy. Encuentros de encariñamiento intercultural andino (Lima: PRATEC).

Rengifo, G. (2002) Allin Kawsay. El Bienestar en la concepción Andino Amazónica (Lima: PRATEC).

Rodríguez, H. (2011) 'Bolivia: entre el desarrollismo y la demagogia pachamamista', Kaosenlared.net, 6/10, http://www.portaloaca.com/opinion/3638-bolivia-entre -el-desarrollismo-y-la-demagogia-pachamamista.html (accessed on 14 October 2016).

Romero, R. and M. Lanza (2012) 'Despatriarcalización y descolonización. Retos desde las políticas públicas', in K. Arkonada (ed.) Transiciones al Vivir Bien (La Paz: Ministerio de Culturas), pp. 51-64.

Santos, B. de S. (2010) 'Hablamos del Socialismo del Buen Vivir', América Latina en Movimiento, 452, pp. 4-7.

Santos, B. de S. (2009) 'Las paradojas de nuestro tiempo y la plurinacionalidad', in A. Acosta and E. Martínez (eds.) Plurinacionalidad. Democracia en la diversidad (Quito: Abya Yala), pp. 21-62.

SENPLADES (Secretaría Nacional de Planificación del Desarrollo) (2012) Transformación de la matriz productiva (Quito: SENPLADES).

SENPLADES (2011) Recuperación del Estado para el Buen Vivir. La experiencia ecuatoriana de transformación del Estado (Quito: SENPLADES).

SENPLADES (2009) Plan Nacional del Buen Vivir 2009-2013 (Quito: SENPLADES).

SENPLADES (2007) Plan Nacional de Desarrollo 2007-2011 (Quito: SENPLADES).

Silva, E. (2002) Mushuk Allpa. La experiencia de los indígenas de Pastaza en la conservación de La selva amazónica (Quito: Amazanga). 
Simbaña, F. (2011) 'El Sumak Kawsay como proyecto político', in A.L. Hidalgo-Capitán, A. Guillén and N. Deleg (eds.) Sumak Kawsay Yuyay (Huelva, España: CIM and PYDLOS, 2014), pp. 245-252.

Stefanoni, P. (2010) 'Indianismo y pachamamismo', Rebelión, 04/05, http://www.rebelion.org/noticia.php?id=105233 (accessed on 14 October 2016).

Svampa, M. (2011) 'Extractivismo neodesarrollista y movimientos sociales ¿Un giro ecoterritorial hacia nuevas alternativas?', in M. Lang and D. Mokrani (eds.) Más allá del desarrollo (Quito: Abya Yala), pp. 185-217.

Temple, D. (2003) Teoría de la reciprocidad (La Paz: GTZ).

Tibán, L. (2000) 'El concepto de desarrollo sustentable y los pueblos indígenas', Boletín ICCI, 18, http://icci.nativeweb.org/boletin/18/tiban.html (accessed on 14 October 2016).

Torrez, M. (2012) Suma Qamaña y Desarrollo. El T'hinkhu necesario (La Paz: COSUDE). Torrez, M. (2001) 'Estructura y proceso de desarrollo del Qamaña', Pacha, 6, pp. 45-67. Tortosa, J.M. (ed.) (2011) Maldesarrollo y mal vivir (Quito: Abya Yala).

Tortosa, J.M. (2009) 'Sumak Kawsay, Suma Qamaña, Buen Vivir', Aportes Andinos, 28, http://repositorio.uasb.edu.ec/handle/10644/2789 (accessed on 14 October 2016).

Unceta, K. (2014) Desarrollo, postcrecimiento y Buen Vivir (Quito: Abya Yala).

Vanhults, J. (2015) 'El laberinto de los discursos del Buen Vivir: entre Sumak Kawsay y Socialismo del siglo XXI', Polis, 40, https://polis.revues.org/10727 (accessed on 14 October 2016).

Vega, E. (2011) 'Descolonizar y despatriarcalizar para vivir bien', in M. Lang and D. Mokrani (eds.) Más allá de desarrollo (Quito: Abya Yala), pp. 257-264.

Vega, F. (2012) 'Teología de la Liberación y Buen Vivir', in A. Guillén and M. Phélan (eds.) Construyendo el Buen Vivir (Cuenca: PYDLOS), pp. 115-136.

Viteri, A. et al. (1992) Plan Amazanga (Puyo, Ecuador: OPIP, mimeo).

Viteri, C. (2003) Súmak Káusai. Una respuesta viable al desarrollo (Quito: Universidad Politécnica Salesiana del Ecuador, Bachelor's Thesis in Applied Anthropology, mimeo).

Viteri, C. (2000) 'Visión indígena del desarrollo en la Amazonía', Polis, 3, https://polis. revues.org/7678 (accessed on 14 October 2016).

Walsh, C. (2010) 'Development as Buen Vivir: Institutional arrangements and (de)colonial entanglements', Development, 53(1), pp. 15-21.

Walsh, C. (2009) 'Estado plurinacional e intercultural: complementariedad y complicidad hacia el Buen Vivir', in A. Acosta and E. Martínez (eds.) Plurinacionalidad. Democracia en diversidad (Quito: Abya Yala), pp. 161-184.

Yampara, S. (2001) El aylluy la territorialidad en los Andes: una aproximación a Chambi Grande (La Paz: Ediciones Qamán Pacha Cada). 